\title{
Potassium fertilization and irrigation with treated wastewater on gas exchange of colored cotton
}

\author{
Breno L. de C. Lima ${ }^{1}$, Ênio F. de F. e Silva ${ }^{1}$, Hugo R. B. Santos ${ }^{2} \&$ Edivan R. de Souza $^{2}$ \\ ${ }^{1}$ Universidade Federal Rural de Pernambuco/Departamento de Engenharia Agrícola/Programa de Pós-Graduação em Engenharia Agrícola. Recife, \\ PE. E-mail: breno.lclima@bol.com.br (Corresponding author) - ORCID: 0000-0001-7630-0542; enio.fsilva@ufrpe.br - ORCID: 0000-0002-8652-503X \\ ${ }^{2}$ Universidade Federal Rural de Pernambuco/Departamento de Agronomia/Programa de Pós-Graduação em Ciência do Solo. Recife, PE. E-mail: \\ hugobentzen@hotmail.com - ORCID: 0000-0001-8020-537X; edivan.rodrigues@ufrpe.br - ORCID: 0000-0002-2442-7266
}

\section{Key words:}

Gossypium hirsutum L. photosynthesis stomatal conductance

\begin{abstract}
A B S T R A C T
The use of treated domestic wastewater in agriculture is promising because it contains essential nutrients for crops, especially for cotton plants. Information on leaf gas exchanges helps to understand the responses of plants to different water and nutrient managements, since they directly affect physiological processes. Thus, the objective of this study was to evaluate the effect of potassium fertilization and irrigation with treated wastewater on the gas exchange of naturally colored cotton plants grown in the semi-arid region of the state of Pernambuco, Brazil, providing a reference for evaluations of responses of cotton plants to abiotic factors. The experiment was conducted in a randomized block design, in a $5 \times 5$ factorial arrangement, with four replications. The treatments consisted of five potassium rates $(0,50,100,150$, and $200 \%$ of the recommended rate for the crop) and five irrigation depths $(50,75,100,125$, and $150 \%$ of the evapotranspiration of the crop). The highest stomatal conductance, transpiration, net assimilation rate, intercellular $\mathrm{CO}_{2}$ concentration, and carboxylation efficiency were found in irrigated plants with 110, 99, 117, 150 , and $113 \%$ of ETc, combined with the potassium rates of $96,113,97,100$, and $100 \%$ of the recommendation rate for the crop, respectively. The increase in irrigation depths increased the diffusion of $\mathrm{CO}_{2}$ of the plants. The highest instantaneous water-use efficiency was found with the irrigation of $150 \%$ of ETc without potassium fertilization. According to the interaction between irrigation depths and potassium rates, the most efficient potassium rate for naturally colored cotton depends on the irrigation depth applied.
\end{abstract}

Palavras-chave:

Gossypium hirsutum L. fotossíntese

condutância estomática

\section{Adubação potássica e irrigação com esgoto tratado nas trocas gasosas do algodoeiro colorido}

\begin{abstract}
R E S U M O
A utilização de esgotos domésticos tratados na agricultura mostra-se promissora por apresentar nutrientes essenciais para culturas, particularmente, no algodoeiro. Nesse sentido, o conhecimento das trocas gasosas foliares auxilia no entendimento de estratégias utilizadas pelas plantas sob manejos de água e nutrientes, uma vez que, os processos fisiológicos são diretamente influenciados por esses fatores. Diante do exposto e com o desígnio de servir como referência na investigação de respostas de plantas do algodoeiro aos fatores abióticos, objetivou-se avaliar o efeito da irrigação com água de esgoto tratado e doses de potássio nas trocas gasosas do algodoeiro colorido no semiárido pernambucano. $\mathrm{O}$ experimento foi em blocos casualizados em esquema fatorial com cinco lâminas de irrigação $(50,75,100,125$ e $150 \%$ da ETc) e cinco doses de potássio $(0,50,100,150$ e $200 \%$ do recomendado para a cultura) com quatro repetições. Os maiores valores para condutância estomática, transpiração, assimilação líquida, concentração intercelular de $\mathrm{CO}_{2}$ e eficiência de carboxilação foram obtidos nas plantas irrigadas com 110, 99, 117, 150 e 113\% da ETc, combinadas às doses de potássio relativas a $96,113,97,100$ e $100 \%$ da recomendação para a cultura. O aumento das lâminas de irrigação proporcionou, também, a maior difusão de $\mathrm{CO}_{2}$ às plantas. A maior eficiência instantânea no uso de água foi na lâmina de $150 \%$ da ETc sem adubação potássica. Pelos dados da interação lâminas de irrigação versus doses de potássio, a dose mais eficiente de potássio ao algodoeiro colorido depende da lâmina de irrigação aplicada.
\end{abstract}




\section{INTRODUCTION}

Treated wastewater can be used in agriculture as a source of water and nutrition for plants, assisting in water savings for human consumption and increasing available water during long periods of drought and less water availability in reservoirs in semi-arid regions (Andrade Filho et al., 2017).

Cotton farming is important for the generation of employment and income. In addition, the use of naturally colored cotton varieties increases agricultural production in this region due to their adaptation to the climatic and soil conditions of the Brazilian semiarid region (Ferraz et al., 2014).

Information on plant physiology is important for the development and application of technologies that improve agricultural crops (Oliveira et al., 2012). Monitoring leaf gas exchange helps to understand the responses of plants to different water and nutrient managements, since they directly affect physiological processes. The dynamics of the net photosynthesis rate, growth, and yield of cotton plants as a function of the soil water availability by applying different irrigation depths were observed by Zonta et al. (2015) and Zhang et al. (2016).

Potassium (K) is important for the physiology of herbaceous cotton plants; it is essential for their growth, productivity, quality, and resistance to stresses (Zörb et al., 2014; Hu et al., 2016; Tsialtas et al., 2016). Deficiency of K results in low plant growth and decreases crop yield (Oosterhuis et al., 2013).

However, large agricultural areas have deficiency of $\mathrm{K}$, especially in sandy, flooded, saline, and acidic soils, especially in intensive production systems, in which it is a limiting nutrient for agricultural production; therefore, $\mathrm{K}$ fertilization is essential (Zörb et al., 2014).

In this context, the objective of this work was to evaluate the effect of potassium fertilization and irrigation with treated wastewater on the gas exchange of naturally colored cotton plants grown in the semi-arid region of the state of Pernambuco, Brazil, providing a reference for evaluations of responses of cotton plants to abiotic factors.

\section{Material AND Methods}

The experiment was conducted from April 15 to August 30, 2016 under field conditions in an experimental area at the Domestic Wastewater Agricultural Reuse Unit of the Department of Agricultural Engineering of the Federal Rural University of Pernambuco, in Ibimirim PE, Brazil (8 32' 05" $\mathrm{S}, 37^{\circ} 41^{\prime} 50^{\prime \prime} \mathrm{W}$, and average altitude of $408 \mathrm{~m}$ ).

The climate of the region was classified as BSh, very hot semi-arid, according to the Köppen classification (Alvares et al., 2013) and has average annual precipitation of $454 \mathrm{~mm}$. The accumulated precipitation during the experimental period was $122 \mathrm{~mm}$, with average temperature of $24.6^{\circ} \mathrm{C}$.
The soil of the experimental area was classified as typical orthic Neossolo Quartzarênico (Psamment), with moderate A horizon, hyper-xerophilous caatinga vegetation, and predominant flat relief, according to EMBRAPA (2014). Soil samples were collected from the $0-20 \mathrm{~cm}$, and $20-40 \mathrm{~cm}$ layers according to the methodology described in Donagema et al. (2011), which showed sandy loam texture - $760 \mathrm{~g} \mathrm{~kg}^{-1}$ (sand), $80 \mathrm{~g} \mathrm{~kg}^{-1}$ (silt), and $160 \mathrm{~g} \mathrm{~kg}^{-1}$ (clay). The soil chemical properties are described in Table 1.

A randomized block experimental design, in a $5 \times 5$ factorial arrangement was used, consisting of 25 treatments with four replications, totaling 100 experimental plots. The treatments consisted of five irrigation depths (ID) - 50, 75, 100, 125 , and $150 \%$ of the crop evapotranspiration (ETc) - using domestic wastewater treated in a UASB (Upflow Anaerobic Sludge Blanket) reactor, and five potassium rates (KR) - 0, 50, 100,150 , and $200 \%$ of the recommended rate for irrigating herbaceous cotton crops - based on the soil analysis, using the fertilization recommendations for the State of Pernambuco (IPA, 2008).

The wastewater analysis presented on averages: electrical conductivity $=2.1 \mathrm{dS} \mathrm{m} \mathrm{m}^{-1} ; \mathrm{pH}=7.2$; total hardness $=$ $273.4 \mathrm{mg} \mathrm{CaCO}{ }_{3} \mathrm{~L}^{-1} ; \mathrm{Ca}^{2+}=74.9 \mathrm{mg} \mathrm{L}^{-1} ; \mathrm{Mg}^{2+}=21.0 \mathrm{mg} \mathrm{L}^{-1}$; $\mathrm{Na}^{+}=133.1 \mathrm{mg} \mathrm{L}^{-1} ; \mathrm{K}^{+}=43.6 \mathrm{mg} \mathrm{L}^{-1}$; total $\mathrm{N}=126.0 \mathrm{mg} \mathrm{L}^{-1}$; total $\mathrm{P}=13.7 \mathrm{mg} \mathrm{L}^{-1} ; \mathrm{S}=5.3 \mathrm{mg} \mathrm{L}^{-1} ; \mathrm{Mn}=1.3 \mathrm{mg} \mathrm{L}^{-1} ; \mathrm{Fe}=$ $9.2 \mathrm{mg} \mathrm{L}^{-1}$; chemical oxygen demand $=154.0 \mathrm{mg}$ of $\mathrm{O}_{2} \mathrm{~L}^{-1}$; biological oxygen demand $=39.0 \mathrm{mg}^{\circ} \mathrm{O}_{2} \mathrm{~L}^{-1}$; dissolved $\mathrm{O}_{2}=$ $46.0 \%$; total coliforms $=2.2 \times 10^{7}$ (most probable number $) / 100$ $\mathrm{mL}$; thermotolerant coliforms $=1.4 \times 10^{7}$ (most probable number)/100 $\mathrm{mL}^{-1}$ (APHA, 2012).

Irrigation management was carried out according to the climatic conditions during the crop development. ETc was calculated based on the daily reference evapotranspiration (ETo) estimated by the Penman-Monteith-FAO model (Allen et al., 1998), using the crop coefficient (Kc) proposed by Bezerra et al. (2010), and location coefficient according to Albuquerque et al. (2012).

The irrigation depths (ID) were controlled by the irrigation time (Ti) established for each treatment with daily irrigations.

The establishment of the crop and thinning operation occurred at 25 days after the emergence of the plants (DAE), when the application of different irrigation depths started by including the $\mathrm{Ti}$, and the correction factor $\mathrm{F}(0.50,0.75$, $1.00,1.25$ and 1.50) in the calculation of the irrigation depths according to the treatments. At the end of the experiment (135 DAE), the accumulated irrigation depths of the treatments were $307.75 \mathrm{~mm}$ (50\% ETc), $461.62 \mathrm{~mm}$ (75\% ETc), $615.49 \mathrm{~mm}$ (100\% ETc), $769.36 \mathrm{~mm}$ (125\% ETc), and $923.24 \mathrm{~mm}$ (150\% ETc).

A drip irrigation system was used, with lateral water distribution lines containing pressure-compensating drip tapes (Dripnet PC 16250, Netafim, Tel Aviv, Israel) of nominal

Table 1. Chemical properties of the soil of the experimental area

\begin{tabular}{ccccccccccccc}
\hline $\begin{array}{c}\text { Soil layer } \\
(\mathbf{m})\end{array}$ & $\begin{array}{c}\mathbf{P} \\
\left(\mathbf{m g ~ d m}^{-3}\right)\end{array}$ & $\begin{array}{c}\mathrm{pH} \\
\mathbf{H}_{2} \mathbf{O}\end{array}$ & $\mathbf{C a}$ & $\mathbf{M g}$ & $\mathbf{N a}$ & $\mathbf{K}$ & $\mathbf{A l}$ & $\mathbf{( H + A l )}$ & $\mathbf{C E C}$ & $\mathbf{S B}$ & $\mathbf{m}$ & $\mathbf{B S}$ \\
$0-0.20$ & 25 & 4.60 & 1.25 & 0.75 & 0.03 & 0.19 & 0.15 & 1.56 & 3.78 & 2.22 & 6 & 59 \\
$0.20-0.40$ & 19 & 4.30 & 1.40 & 0.70 & 0.04 & 0.24 & 0.40 & 2.14 & 4.52 & 2.38 & 14 & 53 \\
\hline
\end{tabular}

$(\mathrm{H}+\mathrm{Al})$ - Potential acidity; CEC - Cation exchange capacity; SB - Sum of bases; $\mathrm{m}$ - Aluminum saturation; BS - Base saturation 
diameter of $16 \mathrm{~mm}$, and drippers spaced $0.30 \mathrm{~m}$ apart with flow rate of $2.0 \mathrm{~L} \mathrm{~h}^{-1}$. A horizontal axis centrifugal pump (Schneider, Rueil-Malmaison, France) of $735.5 \mathrm{~W}$ was used for the effluent suction.

Potassium chloride $\left(\mathrm{KCl}, 60 \% \mathrm{~K}_{2} \mathrm{O}\right)$ was used as $\mathrm{K}$ source for the evaluation of the factor potassium rate (KR). The application of the determined rates consisted of applying 50\% of the rate in the planting furrow, at depth of $0.10 \mathrm{~m}$, before sowing; $25 \%$ as topdressing in the furrow at $0.05 \mathrm{~m}$ from to the planting row, at depth of $0.10 \mathrm{~m}$, after thinning; and $25 \%$ at 20 days after the manure fertilizer application, which was distributed manually in the furrows. The $\mathrm{K}$ rates used were 0 , $20,40,60$, and $80 \mathrm{~kg} \mathrm{~K}_{2} \mathrm{O} \mathrm{ha}^{-1}$, representing 0, 50, 100, 150, and $200 \%$ of the recommended rate, respectively.

The cotton cultivar BRS-Rubi was planted in furrows at depth of $0.05 \mathrm{~m}$, placing five seeds every $0.20 \mathrm{~m}$ in the furrow; 10 plants per meter were left after thinning. Weed control was performed manually using a hoe at 40 DAE when the crop reached full vegetative stage, at the beginning of the flowering stage.

Stomatal conductance (gs, $\mathrm{mol} \mathrm{H}_{2} \mathrm{O} \mathrm{m}^{-2} \mathrm{~s}^{-1}$ ), leaf transpiration rate $\left(\mathrm{E}, \mathrm{mmol} \mathrm{H}_{2} \mathrm{O} \mathrm{m}^{-2} \mathrm{~s}^{-1}\right), \mathrm{CO}_{2}$ net assimilation rate $(\mathrm{A}, \mu \mathrm{mol}$ $\left.\mathrm{CO}_{2} \mathrm{~m}^{-2} \mathrm{~s}^{-1}\right)$, and intercellular $\mathrm{CO}_{2}$ concentration $(\mathrm{Ci}, \mu \mathrm{mol} \mathrm{CO}$ mol air ${ }^{-1}$ ) were evaluated at $130 \mathrm{DAE}$. The data of $\mathrm{A}, \mathrm{Ci}$, and $\mathrm{E}$ were used to calculate the apparent carboxylation efficiency ( $\mathrm{CEa}, \mu \mathrm{mol} \mathrm{CO} \mathrm{Cm}^{-2} \mathrm{~s}^{-1} \mathrm{ppm} \mathrm{CO}_{2}^{-1}$ ) (A to Ci ratio), and the instantaneous water-use efficiency (WUEi, $\mu \mathrm{mol} \mathrm{CO}_{2} \mathrm{mmol}$ $\mathrm{H}_{2} \mathrm{O}^{-1}$ ) (A to E ratio).

Leaf gas exchange were measured between 8 and $11 \mathrm{~h}$ am in the fourth healthy, fully expanded leaf from the apex (the first leaf was the most recently emitted) (Hu et al., 2016) of a random plant from each plot, using an infrared gas analyzer (LI-6400XT, LI-COR, Lincoln, USA).

The data were collected in an open system with the leaf chamber adjusted for photon flux density of $1800 \pm 267 \mu \mathrm{mol} \mathrm{m} \mathrm{m}^{-2} \mathrm{~s}^{-1}$, environmental temperature of $31 \pm 1{ }^{\circ} \mathrm{C}$, and capsular $\mathrm{CO}_{2}$ concentration of $500 \mu \mathrm{mol} \mathrm{CO} \mathrm{mol} \mathrm{air}^{-1}$, approximately.

The data were subjected to analysis of variance, and when the interaction was significant, the means were fitted to multiple regression models (response surface), considering the irrigation depths (ID) and the potassium rates (KR) as independent variables. The SAS 9.0 statistical program (SAS Institute, Cary, USA) was used, using the PROC GLM procedures for analysis of variance and the PROC RSREG for response surface analysis (Zimmermann, 2014).

\section{RESUlTS AND Discussion}

The irrigation depth (ID) and potassium rate (KR) factors presented significant interaction at 0.01 probability level for gas changes of the naturally colored cotton at 130 DAE (Table 2).

Increasing irrigation depths up to $110 \%$ of ETc, and potassium rates up to $96 \%$ of the recommended rate increased stomatal conductance up to $0.3720 \mathrm{~mol} \mathrm{H}_{2} \mathrm{O} \mathrm{m}^{-2} \mathrm{~s}^{-1}$. Irrigation depths and potassium rates above these estimated maximums compromised the stomatal conductance of the naturally colored cotton plants (Figure 1A).

The irrigation depths above $110 \%$ of ETc, and potassium rates above $96 \%$ of the recommended rate subjected the cotton plants to stress due to the excess of these inputs. Silva et al. (2015) found similar results for eggplant crops.

Plants under water stress conditions close their stomata, reducing conductance and, consequently, transpiration, and $\mathrm{CO}_{2}$ assimilation and concentration in the sub-stomatal chamber (Taiz et al., 2017). According to Albuquerque et al. (2011b), application of excessive irrigation depths and $\mathrm{K}$ rates cause higher potassium losses due to leaching, denoting the leaching potential of this element, especially in sandy soils with low CEC. This may explain the decreased conductance with potassium rates above the estimated maximum (96\%).

Catuchi et al. (2012) evaluated soybean crops under irrigation of 40 and $100 \%$ of the field capacity, and potassium rates of 0,90 , and $180 \mathrm{mg} \mathrm{dm}^{-3}$ and found increases in stomatal conductance with increasing potassium rates using the irrigation of $100 \%$, however, it decreased in the water restriction condition (40\%).

The maximum transpiration of plants in response to the interaction ID $\times \mathrm{KR}$ was $7.60 \mathrm{mmol} \mathrm{H}_{2} \mathrm{O} \mathrm{m} \mathrm{m}^{-2} \mathrm{~s}^{-1}$, with irrigation of $99 \%$ of ETc combined with the $\mathrm{K}$ rate of $113 \%$ of the recommended rate $\left(E=-1.992771+0.158872^{\star *} \mathrm{ID}\right.$ $+0.030669^{\star *} \mathrm{KR}-0.000776^{\star \star} \mathrm{ID}^{2}-0.000116^{\star *} \mathrm{KR}^{2}-$

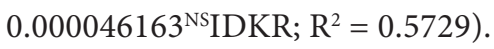

The response of the transpiration, similarly to the stomatal conductance, confirm that it determines the demand that the transpiration rate is potentially subjected, controlling water losses to the environment (Lima et al., 2010; Silva et al., 2015). Plants present high transpiration rates in soil moisture at field capacity, but they decrease expressively with decreasing soil water content, as also found for eggplant crops (Silva et al., 2015).

Increasing irrigation depth up to $117 \%$ of ETc, and $\mathrm{K}$ rates up to $97 \%$ of the recommended rate increases $\mathrm{CO}_{2}$ assimilation rate up to the estimated maximum of $18.64 \mu \mathrm{mol} \mathrm{CO} \mathrm{m}^{-2} \mathrm{~s}^{-1}$;

Table 2. Analysis of variance of stomatal conductance (gs), transpiration (E), $\mathrm{CO}_{2}$ net assimilation rate (A), intercellular $\mathrm{CO}_{2}$ concentration $(\mathrm{Ci})$, carboxylation efficiency (CEa) and instantaneous water-use efficiency (WUEi) of leaves of naturally colored cotton plants under different irrigation depths and potassium rates

\begin{tabular}{|c|c|c|c|c|c|c|c|}
\hline \multirow{2}{*}{ Source of variation } & \multirow{2}{*}{ DF } & \multicolumn{6}{|c|}{ Mean square } \\
\hline & & gs & $E$ & $\bar{A}$ & $\mathrm{Ci}$ & CEa & WUEi \\
\hline Block & 3 & $0.000007^{\mathrm{NS}}$ & $1.6720^{\star *}$ & $2.056352^{\text {NS }}$ & $709.8277^{\star \star}$ & $0.00013^{* *}$ & $0.134729^{\text {NS }}$ \\
\hline Irrigation Depth (ID) & 4 & $0.138124^{* *}$ & $20.4478 * *$ & $186.1721^{\text {** }}$ & $1704.1986^{* *}$ & $0.00232^{* *}$ & 3.245990 ** \\
\hline Potassium Rate (KR) & 4 & 0.035990 ** & $9.5019 * *$ & 19.9220 ** & 852.9031 ** & $0.00014^{* *}$ & $0.536827^{\star *}$ \\
\hline ID $\times$ KR & 16 & $0.004732^{\star \star}$ & $1.5397^{\star \star}$ & $7.1465^{\star \star}$ & $218.8244^{\star \star}$ & $0.00009 * *$ & $0.312096^{\star *}$ \\
\hline Residue & 72 & 0.0002 & 0.2237 & 1.1259 & 36.4856 & 0.00001 & 0.072310 \\
\hline CV (\%) & & 5.84 & 7.83 & 6.94 & 2.4198 & 6.63 & 10.41 \\
\hline
\end{tabular}

DF - Degrees of freedom; ${ }^{* *}$ Significant at 0.01 probability level; ${ }^{*}$ Significant at 0.05 probability level; ${ }^{\text {Ns }}$ Not significant 
A.

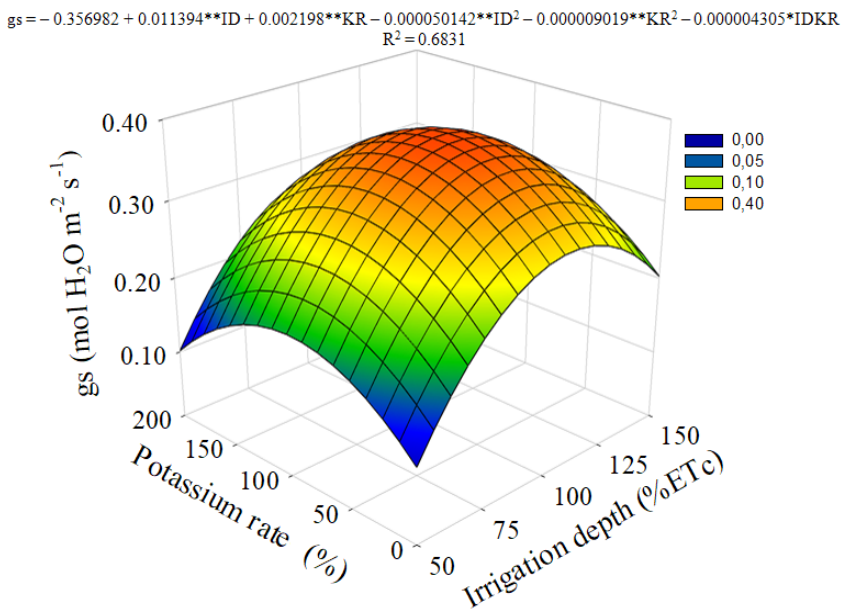

B.

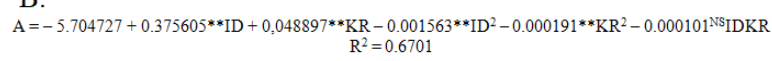

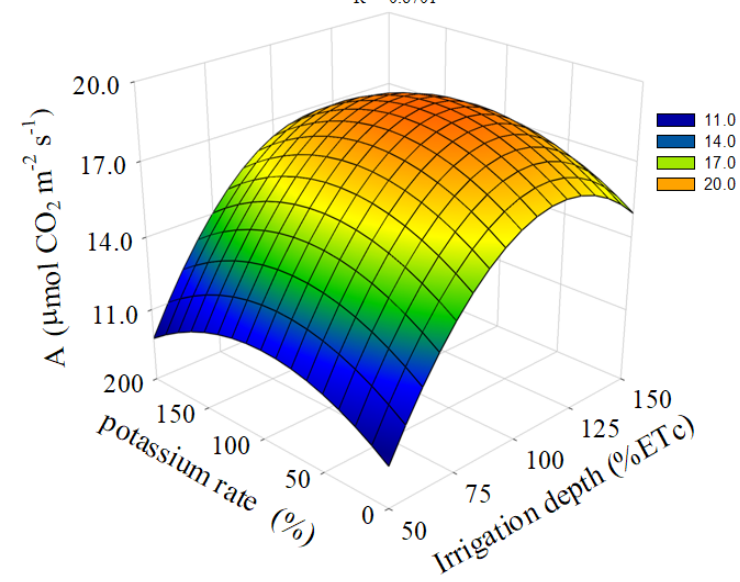

C.

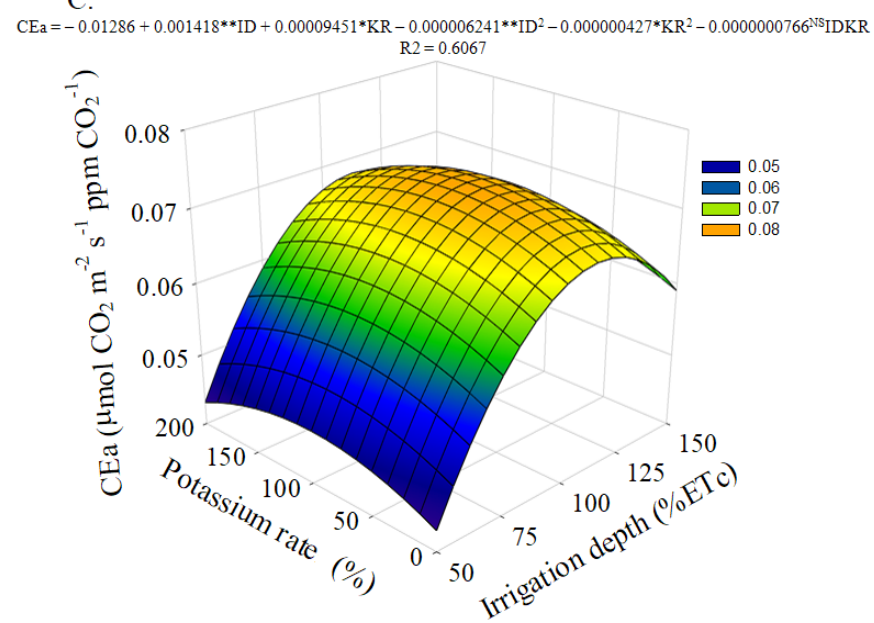

** - Significant at 0.01 probability level; " - Significant at 0.05 probability level; ns- Not significant Figure 1. Response surface of stomatal conductance (A), $\mathrm{CO}_{2}$ net assimilation rate (B) and $\mathrm{CO}_{2}$ carboxylation efficiency (C) of naturally colored cotton plants (cultivar BRS-Rubi), depending on irrigation depths (ID) and potassium rates $(\mathrm{KR})$

however, increases above those $(I D \times K R)$ inhibit the photosynthesis of the naturally colored cotton plants (BRSRubi) (Figure 1B).

According to the quadratic fit of the $\mathrm{CO}_{2}$ assimilation rate as a function of potassium rates, it increased up to the maximum rate of $97 \%$. This result was due to the potassium functions in the stomatal dynamics, and activation of the carboxylase of rubisco, which increases photosynthetic activity (Cakmak, 2005; Catuchi et al., 2012).

The $\mathrm{CO}_{2}$ assimilation rates of the plants decreased with $\mathrm{K}$ rates higher than $97 \%$ of the recommended rate. This was probably due to the reduced stomatal conductance, which was restricted by the intensification of the soil osmotic effect caused by the composition of the treated domestic wastewater accumulated throughout the cotton cycle. The treated domestic wastewater presented $74.9 \mathrm{mg} \mathrm{L}^{-1}$ of calcium, $21.0 \mathrm{mg} \mathrm{L}^{-1}$ of magnesium, $133.1 \mathrm{mg} \mathrm{L}^{-1}$ of sodium, $43.6 \mathrm{mg} \mathrm{L}^{-1}$ of potassium, and electrical conductivity of $2.1 \mathrm{dS} \mathrm{m}^{-1}$.

Leaf gas exchanges and crop growth are strongly affected by irrigation and potassium fertilization, thus, the interaction between these factors indicates that the potassium rate depends on the applied irrigation depth (Albuquerque et al., 2011a; Catuchi et al., 2012).

Intercellular $\mathrm{CO}_{2}$ concentration increased linearly as a function of irrigation depths, presenting a quadratic fit for potassium rates. The maximum intercellular $\mathrm{CO}_{2}$ concentration (Ci) $\left(271.37 \mu \mathrm{mol}\right.$ of $\mathrm{CO}_{2}$ molar $\left.^{-1}\right)$ was found using the irrigation depth of $150 \%$ of ETc, combined with the potassium rate of $100 \%\left(\mathrm{Ci}=203.2304+0.4021^{\star} \mathrm{ID}+0.4358^{\star \star} \mathrm{KR}-\right.$ $\left.0.0001^{\mathrm{NS}} \mathrm{ID}^{2}-0.0013^{\star \star} \mathrm{KR}^{2}-0.0013^{\star *} \mathrm{IDKR} ; \mathrm{R}^{2}=0.5802\right)$.

$\mathrm{Ci}$ was higher in the greatest irrigation depth applied, confirming the results of Silva et al. (2015), who found increased $\mathrm{CO}_{2}$ concentrations in eggplants with increasing irrigation depths. According to these results, irrigation is a limiting factor for $\mathrm{CO}_{2}$ assimilation in cotton plants, as also reported by Catuchi et al. (2012).

In general, stomatal conductance (gs) increases together with $\mathrm{Ci}$. Thus, stomatal restrictions reduce the photosynthetic performance of plants, with negative effects in $\mathrm{CO}_{2}$ diffusion to the sub-stomatal chamber ( $\mathrm{Hu}$ et al., 2016; Tsialtas et al., 2016). According to Ferraz et al. (2014), Ci decreases are due to decreases in $\mathrm{CO}_{2}$ net assimilation rates, since $\mathrm{CO}_{2}$ absorption leads to water losses, thus, water reductions decrease $\mathrm{CO}_{2}$ assimilation, decreasing the $\mathrm{Ci}$.

The increase in $\mathrm{Ci}$ with increasing irrigation depths is explained by the instantaneous water use efficiency (WUEi), which also increases with increasing irrigation depths, resulting in plants that diffuse more $\mathrm{CO}_{2}$ by water loss, showing increasing linear effect for $\mathrm{Ci}$.

The apparent $\mathrm{CO}_{2}$-carboxylation efficiency (CEa) presented quadratic response to the ID $\times \mathrm{KR}$ interaction, with maximum $\mathrm{CEa}\left(0.0720 \mu \mathrm{mol} \mathrm{CO} \mathrm{m}^{-2} \mathrm{~s}^{-1} \mathrm{ppm} \mathrm{CO}_{2}^{-1}\right)$ using irrigation depth of $113 \%$ of ETc, and $\mathrm{K}$ rate of $100 \%$ of the recommendation rate (Figure $1 \mathrm{C}$ ).

Increasing irrigation depths increases soil water availability and, consequently, stomatal conductance, which combined with the higher $\mathrm{Ci}$, increases $\mathrm{CEa}$ due to the increase in $\mathrm{CO}_{2}$ assimilation. Thus, CEa depends on the $\mathrm{Ci}$ in the mesophyll, as well as on abiotic factors for photosynthesis (Silva et al., 2015).

The maximum WUEi $\left(3.42 \mu \mathrm{mol} \mathrm{CO}_{2} \mathrm{mmol} \mathrm{H}_{2} \mathrm{O}^{-1}\right)$ was found in leaves from irrigated plants with $150 \%$ of ETc, regardless of the potassium rate $(\mathrm{WUEi}=2.4340-$ $0.0041^{\mathrm{NS}} \mathrm{ID}-0.0047^{\star} \mathrm{KR}+0.000071^{\star} \mathrm{ID}^{2}+0.000017^{\star} \mathrm{KR}^{2}-$ $\left.0.0000015^{\mathrm{NS}} \mathrm{IDKR} ; \mathrm{R}^{2}=0.5588\right)$. 
Increases in WUEi were also found by Brito et al. (2012) in citrus cultivars with increasing irrigation depths. The highest water availability generated by the irrigation depth of $150 \%$ ETc, reduced the transpiration of cotton plants, which is controlled by stomatal resistance. Considering that WUEi is the ratio between the plant's assimilated $\mathrm{CO}_{2}$ and water loss, and the highest $\mathrm{CO}_{2}$ assimilation rates occurred with irrigation depths of approximately $150 \%$ of ETc, an increase in WUEi denotes that plants under of excessive irrigation depths have greater $\mathrm{CO}_{2}$ diffusion as a response to water loss.

Regarding the applied potassium rates, although the variations of WUEi as a function of $\mathrm{K}$ rates were significant, they were lower than $1.0 \mu \mathrm{mol} \mathrm{CO} \mathrm{Cmol} \mathrm{H}_{2} \mathrm{O}^{-1}$, regardless of the applied irrigation depth.

Potassium is important for the plant physiology, however, the WUEi of naturally colored cotton plants seems to be controlled primarily by soil water availability. The reduced conductance limited more the water loss (transpiration) than $\mathrm{CO}_{2}$ net assimilation rate (A) by the stomata, increasing WUEi with increasing irrigation depths, which is an indicative of tolerance of this species to water stress.

This effect was observed for the applied $\mathrm{K}$ rates, showing maintenance of transpiration to the detriment of photosynthesis, causing a low variation of WUEi with increasing K rates. Nonvariation of WUEi as a function of potassium fertilization was also found by Catuchi et al. (2012) in soybean cultivars, and by Tsialtas et al. (2016) in cotton cultivars.

\section{Conclusions}

1. Based on the interaction between the treated domestic wastewater irrigation depths and potassium rates used, the potassium application rate required by naturally colored cotton plants depends on the irrigation depth applied.

2. The application of a treated domestic wastewater irrigation depth of $117 \%$ of ETc combined with potassium rate of $97 \%$ of the recommended potassium rate for cotton crops resulted in the highest $\mathrm{CO}_{2}$ net assimilation rate.

3. Irrigation with treated domestic wastewater depths greater than the crop evapotranspiration and application of the recommended rates of potassium for naturally colored cotton crops to obtain the maximum efficiency of gas exchanges is recommended.

\section{Literature Cited}

Albuquerque, F. S.; Silva, Ê. F. de F. e; Albuquerque Filho, J. A. C.; Lima, G. S. Necessidade hídrica e coeficiente de cultivo do pimentão fertirrigado. Irriga, v.17, p.481-493, 2012. https://doi. org/10.15809/irriga.2012v17n4p481

Albuquerque, F. S.; Silva, Ê. F. de F. e; Albuquerque Filho, J. A. C.; Nunes, M. F. F. N. Growth and yield of sweet pepper fertigated under different irrigation depths and potassium doses. Revista Brasileira de Engenharia Agrícola e Ambiental, v.15, p.686-694, 2011a. https://doi.org/10.1590/S1415-43662011000700006

Albuquerque, F. S.; Silva, Ê. F. de F. e; Souza, A. E. R.; Rolim, M. M. Lixiviação de potássio em um cultivo de pimentão sob lâminas de irrigação e doses de potássio. Revista Caatinga, v.24, p.135$144,2011 b$.
Allen, R. G.; Pereira, L. S.; Raes, D.; Smith, M. Crop evapotranspiration: Guidelines for computing crop water requirements. Rome: FAO, 1998. 300p. Irrigation and Drainage, Paper 56

Alvares, C. A.; Stape, J. L.; Sentelhas, P. C.; Gonçalves, J. L. de M.; Sparovek, G. Köppen's climate classification map for Brazil. Meteorologische Zeitschrift, v.22, p.711-728, 2013. https://doi. org/10.1127/0941-2948/2013/0507

Andrade Filho, J.; Nascimento, I. B.; Sousa Neto, O. N.; Dias, N. da S.; Rivera, R. C.; Portela, J. C.; Costa, J. D. Foliar content of $\mathrm{N}, \mathrm{P}$ and $\mathrm{K}$ in cotton fertigated with treated sewage effluents. Revista de Ingeniería DYNA, v.84, p.147-154, 2017. http://dx.doi. org/10.15446/dyna.v84n202.61916

APHA - American Public Health Association. Standard methods for examination of water and wastewater. 22.ed. Washington: American Public Health Association, 2012. 1360p.

Bezerra, J. R. C.; Azevedo, P. V. de; Silva, B. B. da; Dias, J. M. Evapotranspiração e coeficiente de cultivo do algodoeiro BRS-200 Marrom, irrigado. Revista Brasileira de Engenharia Agrícola e Ambiental, v.14, p.625-632, 2010. https://doi.org/10.1590/S141543662010000600009

Brito, M. E. B.; Soares, L. A. dos A.; Fernandes, P. D.; Lima, G. S. de; Sá, F. V. da S.; Melo, A. S. de. Comportamento fisiológico de combinações copa/porta-enxerto de citros sob estresse hídrico. Revista Brasileira de Ciencias Agrárias, v.7, p.857-865, 2012. https://doi.org/10.5039/agraria.v7isa1941

Cakmak, I. The role of potassium in alleviating detrimental effects of abiotic stresses in plants. Journal of Plant Nutrition and Soil Science, v.168, p.521-530, 2005. https://doi.org/10.1002/ jpln.200420485

Catuchi, T. A.; Guidorizzi, F. V. C.; Guiorizi, K. A.; Barbosa, A. M.; Souza, G. M. Respostas fisiológicas de cultivares de soja à adubação potássica sob diferentes regimes hídricos. Pesquisa Agropecuária Brasileira, v.47, p.519-527, 2012. https://doi. org/10.1590/S0100-204X2012000400007

Donagema, G. K.; Campos, D. V. B.; Calderano, S. B.; Teixeira, W. G.; Viana, J. H. M. Manual de métodos de análises de solos. 2.ed. Rio de Janeiro: Embrapa Solos, 2011. 230p.

EMBRAPA - Empresa Brasileira de Pesquisa Agropecuária. Sistema brasileiro de classificação de solos. 4.ed. Rio de Janeiro: Embrapa Solos, 2014. 353p.

Ferraz, R. L. S. de; Beltrão, N. E. de M.; Melo, A. S. de; Magalhães, I. D.; Fernandes, P. D.; Rocha, M. S. Trocas gasosas e eficiência fotoquímica de cultivares de algodoeiro herbáceo sob aplicação de silício foliar. Semina: Ciências Agrárias, v.35, p.735-748, 2014. https://doi.org/10.5433/1679-0359.2014v35n2p735

Hu, W.; Jiang, N.; Yang, J.; Meng, Y.; Wang, Y.; Chen, B.; Zhao, W.; Oosterhuis, D. M.; Zhou, Z. Potassium (K) supply affects $\mathrm{K}$ accumulation and photosynthetic physiology in two cotton (Gossypium hirsutum L.) cultivars with different K sensitivities. Field Crops Research, v.196, p.51-63, 2016. https://doi. org/10.1016/j.fcr.2016.06.005

IPA - Instituto Agronômico de Pernambuco. Recomendações de adubação para o Estado de Pernambuco. 2.aprox. 3.ed. rev. Recife: Instituto Agronômico de Pernambuco, 2008. 212p.

Lima, M. de A.; Bezerra, M. A.; Gomes Filho, E.; Pinto, C. de M.; Enéas Filho, J. Trocas gasosas em folhas de sol e sombreadas de cajueiro anão em diferentes regimes hídricos. Revista Ciência Agronômica, v.41, p.654-663, 2010. https://doi.org/10.1590/ S1806-66902010000400020 
Oliveira, F. de A. de; Medeiros, J. F. de; Oliveira, F. R. A. de; Freire, A. G.; Soares, L. C. da S. Produção do algodoeiro em função da salinidade e tratamento de sementes com regulador de crescimento. Revista Ciência Agronômica, v.43, p.279-287, 2012. https://doi.org/10.1590/S1806-66902012000200010

Oosterhuis, D. M.; Loka, D. A.; Raper, T. B. Potassium and stress alleviation: Physiological functions and management of cotton. Journal of Plant Nutrition and Soil Science, v.173, p.331-343, 2013. https://doi.org/10.1002/jpln.201200414

Silva, F. G.; Dutra, W. F.; Dutra, A. F.; Oliveira, I. M.; Filgueiras, L. M. B.; Melo, A. S. Trocas gasosas e fluorescência da clorofila em plantas de berinjela sob lâminas de irrigação. Revista Brasileira de Engenharia Agrícola e Ambiental, v.19, p.946952, 2015. https://doi.org/10.1590/1807-1929/agriambi. v19n10p946-952

Taiz, L.; Zeiger, E.; Moller, I. M.; Murphy, A. Fisiologia e desenvolvimento vegetal. 6.ed. Porto Alegre: Artmed, 2017. 888 p.
Tsialtas, I. T.; Shabala, S.; Baxevanos, D.; Matsi, T. Effect of potassium fertilization on leaf physiology, fiber yield and quality in cotton (Gossypium hirsutum L.) under irrigated Mediterranean conditions. Field Crops Research, v.193, p.94-103, 2016. https:// doi.org/10.1016/j.fcr.2016.03.010

Zhang, D.; Luo, Z.; Liu, S.; Li, W.; Tang, W.; Dong, H. Effects of deficit irrigation and plant density on the growth, yield and fiber quality of irrigated cotton. Field Crops Research, v.197, p.1-9, 2016. https://doi.org/10.1016/j.fcr.2016.06.003

Zimmermann, F. J. P. Estatística aplicada à pesquisa agrícola. 2.ed. Brasília: Embrapa Informação Tecnológica, 2014. 582p.

Zonta, J. H.; Bezerra, J. R. C.; Sofiatti, V.; Brandão, Z. N. Yield of cotton cultivars under different irrigation depths in the Brazilian semi-arid region. Revista Brasileira de Engenharia Agrícola e Ambiental, v.19, p.748-754, 2015. https://doi.org/10.1590/18071929/agriambi.v19n8p748-754

Zörb, C.; Senbayram, M.; Peiter, E. Potassium in agriculture: Status and perspectives. Journal of Plant Physiology, v.171, p.656-669, 2014. https://doi.org/10.1016/j.jplph.2013.08.008 